\title{
Get Shorty: Steven Pinker on the Enlightenment
}

\author{
Geoffrey Galt Harpham
}

\begin{abstract}
Steven Pinker's Enlightenment Now makes a powerful argument that by every measure, the conditions of human life have been improving steadily for the past 200 years. This improvement can be attributed not just to the spread of the principles of enlightenment announced in the eighteenth century but also to the evolved properties of the human mind, which have been liberated by modernity. Pinker writes in support of this development and in opposition to the ideological and academic resistances to it. His book has itself generated resistance among those he criticizes, and while many of these criticisms are unwarranted, Pinker's book raises serious questions that it does not fully address.
\end{abstract}

Keywords: Pinker, evolution, enlightenment, reason, science, humanism

\section{BOOK UNDER REVIEW}

Steven Pinker, Enlightenment Now: The Case for Reason, Science, Humanism, and Progress. 2018. New York: Viking. xix, 556 pages. Hardcover $\$ 35$; softcover $\$ 18.99$; audiobook download $\$ 27.50$; audiobook CD $\$ 55.00 .556$ pp.

If I could go back in time, I might confront [Nietzsche] as follows: "I am a superman: hard, cold, terrible, without feelings and without conscience. As you recommend, I will achieve heroic glory by exterminating some chattering dwarves. Starting with you, Shorty. And I might do a few things to that Nazi sister of yours, too."

— Steven Pinker, Enlightenment Now: The Case for Reason, Science, Humanism, and Progress (446).

Steven Pinker is in a very good mood, and why not? Handsome, clever, and rich, with a happy disposition, Pinker seems to unite some of the best blessings of existence, including brilliance, an insatiable curiosity, intellectual confidence of an extraordinary kind, a prodigious capacity for work, a phenomenal fund of information on many subjects, and a joie de vivre that communicates itself even in photographs. This fortunate confluence has found expression in the form of a new book, Enlightenment Now: The Case for Reason, Science, Humanism, and Progress, which attempts to prove that the world is becoming more ... "Pinkerish," that is to say, more of everything we admire and desire and less of everything we fear and deplore.
The attributes listed above, some of which were bestowed by a beneficent nature in peaceable Canada, while others have been nurtured in the supportive environments of MIT and Harvard, constitute a negative inventory of the qualities currently associated with the academic profession, which is more often described as defensive, depressed, dyspeptic, self-righteous, intolerant, and arrogant. So it is perhaps not surprising that, his gifts and contributions notwithstanding, Pinker is the object of considerable distrust, resentment, and condescension. Pinker seems to understand in advance the response his book will generate, and writes, in a happy-warrior-bring-it-on mode, against it but also in a kind of festive dialogue with it. 
While the book has been widely praised in the popular press, academic discussions and reviews in the more prestigious newspapers have often registered a professional indignation. David Bell, a professor at Princeton, describes Pinker as a "PowerPoint philosophe," the author of "a dogmatic book that offers an oversimplified, excessively optimistic vision of human history and a starkly technocratic prescription for the human future" (2018). John Semley of the University of Toronto describes Pinker as "a prominent egghead who writes and composes himself with Spock-like coldness and clarity" (2018). Jennifer Szalai, the new book critic of the New York Times, complains that Pinker offers "a jarring blend of chipper triumphalism and unfeeling sang froid . . . a profoundly maddening book" (2018). John Gray of Oxford University, who has been described as Pinker's antipode on the "GrayPinker scale" grading from gloom and doom to cheerful confidence- and who is described in the book as "an avowed progressophobe" — calls the book "embarrassingly feeble. . . a parody of Enlightenment thinking at its crudest," a "comic-book history.” About Pinker's compendium of statistics, Gray says, "Of course, these figures settle nothing” (2018).

The case these writers find so feeble, jarring, and embarrassing is prosecuted over more than 500 conspicuously unembarrassed pages, with dozens of graphs and many hundreds of footnotes citing nearly 3,000 sources, all pointing toward the conclusion that "The world has made spectacular progress in every single measure of human well-being" (52). The calamities and crises of the past couple of centuries notwithstanding, well-being, in all its aspects and dimensions, has been advancing like a Roman legion plowing through Gaul. We are becoming freer, richer, nicer, cleaner, happier, kinder, safer, taller, healthier, and in general more in control of our lives than at any time in the past. The expected human lifespan has been increasing five hours a day for the last 50 years. We are 37 times less likely to be struck by lightning than we were at the turn of the twentieth century. Smallpox and other diseases have been eradicated, and Ebola, SARS, mad cow disease and other viral threats have been neutralized. And the longer we live the smarter we get: as a consequence of education, human beings are measurably more intelligent than they used to be, better able to think abstractly and analytically than our great-grandparents (who, if they were plunked down in our world, would be "borderline retarded by our standards") (241). What others call unwarranted optimism Pinker calls a simple recognition of the facts, vast numbers of them.

The reason for these amazing improvements in the human condition, according to Pinker, is that a critical mass of human beings, concentrated in but not confined to the West, have embraced the ideals of reason, science, and humanism that were articulated during the period now known as the Enlightenment. This embrace has produced progress, and progress of a particularly irresistible kind because the Enlightenment mind-set contains "self-healing powers," a kind of rationality gyroscope that identifies setbacks, wrong turns, or undesirable anomalies, and sets to work eliminating them (383). That they do get eliminated can be seen when history is seen from a distance. What might seem world-altering catastrophes-say, the slaughters of the twentieth century-can, Pinker demonstrates, be represented as temporary negatives, statistical outliers, little notches in a generally upward trendline as long as the span of time represented is sufficiently great.

Terrorists, for example, are horrifying, but constitute a vanishingly small threat. As a proportion of all deaths from terrorism, war, homicide, and accidents, terrorist killings cannot even be represented on a graph since the number would be less than a pixel. Terrorists themselves are a multiply endangered species whose numbers will continue to shrink not just because each successful suicidal attack reduces the cohort, but also because their raison d'être, or perhaps, their raison de ne pas être, effectively restricts recruitment to that portion of the 
population that is maniacal, depraved, disturbed, and "not the brightest bulb in the box" (304). "I venture," Pinker says in a moment of statistical reverie, "that the proportion of brilliant terrorists in a population is even smaller than the proportion of terrorists multiplied by the proportion of brilliant people" (303).

Other challenges are more difficult to argue away. Even Bill Gates, who has pronounced this his "new favorite book of all time," displacing Pinker's The Better Angels of Our Nature (2011), is more concerned than Pinker about the growth of artificial intelligence, asking, not quite rhetorically, "Who exactly controls the robots?" (Gates 2018). And Pinker himself acknowledges the seriousness of the threat presented by climate change. Still, he argues, predicted catastrophes have not occurred and promising trends have begun to establish themselves. Reason, informed by science, is leading the way. Such measures as carbon pricing, market incentives, nuclear energy (which is safer and cheaper in France than in the United States because of a national consensus on best practices in design, fabrication, and construction), restoring coastal and marine habitats, and if all else fails, various forms of "climate engineering" will be sufficient to meet the challenge as long as "the benevolent forces of modernity" can be sustained in the face of mendacious political and corporate influences $(153,155)$.

Pinker believes that we simply cannot be so foolish as to commit species suicide when the tools for averting that fate are so ready to hand. But he notes again and again that some of us are apparently foolish enough to mount moralizing resistance to those tools. "Traditional Greens and the climate justice left," well-meaning do-gooders whose apocalyptic pronouncements are "laced with misanthropy, including an indifference to starvation, an indulgence in ghoulish fantasies of a depopulated planet, and Nazilike comparisons of human beings to vermin," would do the world a favor if they would just shut up and let the scientists and engineers do their work $(151,122)$. The world is not, as the
Greens would have it, "a pristine ingénue which has been defiled by human rapacity"; moreover, "resources just refuse to run out," and if they do we can always find others $(122,126)$. So be of good cheer, Pinker counsels, and while we're busy earnestly limiting things, we might consider limiting the word sustainable, the frequency of which, according to the one graph not meant to be taken seriously, will, if current trends continue, increase to the point where, by 2110 , "all sentences are just the word 'sustainable' repeated over and over" (128).

In their defense, environmentalists are, in Pinker's account, merely part of a larger phenomenon of Enlightenment-denial by people who, for some reason, want to block their ears against good news. "It sounds mad," he says, "but in the $21^{\text {st }}$ century . . c counter-Enlightenment ideas continue to be found in a surprising range of elite cultural and intellectual movements," including religion and politics but also, to Pinker's immense irritation, "among many of our most adored intellectuals and in our most august institutions of higher learning" $(30,387)$. The most adored intellectuals of all cluster in humanities departments. While Pinker is not unfriendly toward the disciplines of the humanities - and even has a number of helpful suggestions about possible humanitiesscience collaborations - he notes that the ranks of humanists contain many soi-disant progressives who "really hate progress" and who hold science accountable for "racism, imperialism, world wars, and the Holocaust," not to mention (although they do) "robbing life of its enchantment and stripping humans of freedom and dignity" (39, 34).

Progressophobia based on misguided principle, simple ignorance, or, most commonly, both, Pinker views as a kind of cultural crime, and he is not above posting a "Most Wanted" list. You would have to go a long way to find a thinker with a longer hit-list than his, which includes, in addition to those previously mentioned, Martin Heidegger, Jacques Derrida, Michel Foucault, Jacques Lacan, "morose cultural pessimists" 
generally, "social justice warriors" generally, postmodernism, deconstruction, Cornel West, Edward Said, Franz Fanon, Frankfurt School Critical Theory, bioethicists, rational-choice theorists, Republicans, irrational religious fundamentalists, regulatory over-reachers, the media, righteous campus lefties, "theoconservatives," professional prognosticators, and Thomas Piketty (406, 373, 448).

In the view of such people, the pretensions of science to rationality or objectivity must be decoded as the stratagems of self-interested power, a premise that leads to . . . to a 2016 article on glaciers published in the journal Progress in Human Geography, which proposes a new "feminist glaciology framework" based on a merger of "feminist postcolonial science studies and feminist political ecology," which will be capable of generating a "robust analysis of gender, power, and epistemologies in dynamic social-ecological systems, thereby leading to more just and equitable science and humanice interactions" (Carey, et al. 2016; quoted in Pinker 2018, 396). Don't Other the Ice! Many humanists feel that today's liberal arts curricula skew disastrously toward the STEM disciplines, but in Pinker's view, those same humanists have so poisoned the well against science that students who might do useful work in the field graduate with a trifling acquaintance of science and a general conviction that it is a wicked business_-and head for Wall Street instead.

Suspicion of science and reason goes hand in hand with catastrophism and an attitude of knowing resignation that, in the current academic climate, often passes for intelligence. It has long been a kind of requirement for entry into some (not all) of the best academic circles that one agree that every comforting or consoling thought, every lofty ambition, every idealistic utterance, every aspiration, every abstract value or virtue, and every imminent reconciliation is a naïve delusion implicated in its opposite. One graduate student told me what he learned in a course in American intellectual history taught at a prestigious university:
"Everyone I thought was a hero turned out to be a villain," he said, "and everyone I thought was a villain turned out to be more villainous than I had imagined."

Villainy has an audience in contemporary academia. Walter Benjamin wrote, "There is no document of civilization which is not at the same time a document of barbarism." These words, extracted from their context, which refers not just to the "document" but to the historical process by which artifacts are transmitted from victor to victor through history, have been recycled to the point where they constitute a humanist's version of $\mathrm{E}=\mathrm{mc}^{2}$, an immense triumph of critical intelligence expressed with diamond density in the simplest possible formula. The sense that culture, or "civilization," is, as Pinker puts it, a "flaming dumpster," finds an echo in a media culture predisposed to the sensationally appalling, where it mutates and ramifies, shredding notions of truth, dignity, and civility — and reason, science, and humanism —as it goes. The result, in Pinker's analysis: authoritarian populism and the rise of the charismatic autocrat who "alone can fix it" (Trump 2016). The road from feminist glaciology to Trump is not straight, but for Pinker it is unbroken.

If the kind of lunacy Pinker finds all around him could be condensed into a single luminous figure, that would be Friedrich Nietzsche, the subject of the thought-experiment quoted at the beginning of this essay. There is for Pinker no more telling mark of the beast in contemporary intellectual culture than the veneration of Nietzsche, whose "genocidal ravings . . . sound like they come from a transgressive adolescent who has been listening to too much death metal" (445). Hitler and Mussolini, or at least their brainier followers, found much to admire in Nietzsche, as did the ideologues behind other "megadeath movements of the 20th century," along with Martin Heidegger and Carl Schmitt (445). An admiration for Nietzsche correlates, Pinker argues, with a widespread "tyrannophilia," as the intellectual historian Mark Lilla calls it, that enlisted eminent intellectual champions 
in defense of virtually every major autocrat of the 20th century, including Mussolini, Lenin, Stalin, Mao, the Ayatollah Khomeini, and Castro. Pinker's research into this subject is characteristically thorough; he digs up a 1969 article in Ramparts in which Susan Sontag, praising the "spontaneity, gaiety, sensuality and freaking out" of post-revolutionary Cuban culture, counseled Americans to "maintain some perspective" when the regime gets "a little up-tight about sexual morals" and rounds up thousands of homosexuals and sends them to forced labor camps "to rehabilitate themselves” (Sontag 1969, quoted in Pinker 2018, 376-77). Ouch.

It is notable that Pinker, whose extraordinary range of sources so often includes recherché material not findable through Google, relies for his Nietzsche quotes on secondary sources. Taken in bits, as Pinker does, Nietzsche can be appalling. He lacks restraint. But for this reason, his thinking is exceptionally bold, and disturbing in many ways, not all of which are enlightened. Pinker is right to be disturbed. But he may have missed the real center of the target in Nietzsche, the widely cited account in "On Truth and Lies in an Extra-Moral Sense" of truth as "a mobile army of metaphors, metonyms, and anthropomorphisms - in short, a sum of human relations, which have been enhanced, transposed, and embellished poetically and rhetorically, and which after long use seem firm, canonical, and obligatory to a people" (Nietzsche 1954, 42). Nietzsche's bloodier passages may have been cited in retrospect by murderers, but it is unlikely that any peaceable person became a murderer only after reading him. But this account of truth has been directly influential on many of those in a position to pronounce on such things, and they have contributed to the anti-science attitudes that Pinker deplores.

Even more interestingly, Pinker may have missed an opportunity to claim an unexpected ally in Nietzsche. It was Nietzsche, after all, who virtually invented the God-is-dead atheism Pinker here advocates, and did so in far more emphatic terms than Pinker, who merely complains that religion is irrational and should defer to reason, science, and humanism on all questions relating to human conduct, including morality. And it was Nietzsche who drew the necessary consequence from the death of God, that people are responsible, as Pinker puts it, "for the welfare of ourselves, our species, and our planet" (395).

This is the urgent Nietzschean message of Enlightenment Now: not that everything is getting better or that progress has many enemies, but that the world is ours to make or repair, to which he adds that our history has proven that we can make it better because we are, well, not Overmen but a rational problem-solving species fully up to the task.

Sturdy convictions about human nature informed Pinker's work even when he was an assistant professor at MIT working on visual cognition and children's acquisition of past tenses (Pinker and Bloom 1990, 290). His first trade book, The Language Instinct (1994) was written in support of the work of his MIT colleague Noam Chomsky, who had devoted himself to developing formal support for the claims that the capacity for language was part of the human genetic equipage, that it was centered in the individual not in society, and that its essence was creative freedom. Although Chomsky insisted that his scientific work had no connection whatsoever to his political convictions, his claims about the language faculty could easily be translated into a heavily moralized freedom-centered politics, which gained traction from the claim that it was grounded in a specifically human nature: humans, Chomsky declared, are "metaphysically distinct from non-humans" (Chomsky 1977, 92).

Pinker wrote The Language Instinct in part to support Chomsky's work by explaining in evolutionary terms how language had become a human instinct. Having at that time no sharply etched moral or political convictions to defend, Pinker could not seem to grasp the importance for Chomsky of a metaphysical distinction between humans and animals, and was mysti- 
fied as to why Chomsky would insist on it. With the passage of time, Pinker has become more politically engaged and committed to a general liberalism, or non-dogmatic libertarianism, grounded, like Chomsky's position, in the values of the Enlightenment and a robust account of human nature but distinct from Chomsky in two ways: Pinker's evolutionary account blurs or erases "metaphysical" differences between humans and their primate ancestors, and he treats language as an adaptation developed not for creative expression but for information-sharing. We occupy an "informavore" niche, and our capacity to gather, process, and share information is the key to our survival, the only way, he points out in Enlightenment Now, that we can combat the universal drag of entropy. Where the political emphasis in Chomsky's work generally falls on the dastardly machinations of power in constraining individual creativity, the emphasis in Pinker is on our capacity to improve our lot collectively, little by little.

For both Chomsky and Pinker, the Enlightenment is an era when human nature received a giant boost from philosophy, which suddenly conformed itself to universal principles-individual freedom for Chomsky, reason-science-humanism for Pinker-thus providing conceptual support for general principles of human flourishing. But neither thinker is really interested in intellectual history as anything other than ancillary evidence for their arguments about human nature.

Many critics of Enlightenment Now have failed to grasp this fact. With, admittedly, some justification, they criticize Pinker for being an imperfect intellectual historian, a vulgarian unable to appreciate the depth, the nuance, the ambiguities of this complex philosophical movement. John Gray begins and ends his attack on Pinker by triumphantly citing Hume's remark that "Reason is, and ought only to be the slave of the passions, and can never pretend to any other office than to serve and obey them" (Hume 2007, 870). Pinker has clearly not read this famous quotation, Gray charges, and has thus missed altogether the darker, weaker, and more circumspect understanding of reason that the Enlightenment actually had. What an ignoramus! How feeble! How embarrassing! But in Hume's account, it is not reason that is responsible for passion's missteps, but rather "false judgments" that inform, or misinform passion. Hume says explicitly that passion informed by true judgments is entirely consistent with reason. To which Pinker might add that the desire to create a world that supports human flourishing is altogether true in that sense, and thus that reason, especially when conjoined with science and humanism-sources of true judgment-is what he says it is.

\section{Or is it?}

Some years ago, Pinker's distinguished colleague at Harvard, Robert Nozick, wrote The Nature of Rationality, in which he described rationality as a product of evolution that has come to define and symbolize "the distance we have come from mere animality" (Nozick 1994, 181). Nozick compared rationality to skin pigment and other traits that everyone has, but some more than others. Rationality has sunk particularly deep roots in "Western societies," where it has been able to "extend its sway," much as the West itself has come to dominate other societies (180). Although described in dauntingly (and to most people incomprehensibly) technical terms, Nozick's rationality has much in common with Pinker's vernacular account of reason, including the crucial self-correcting mechanism (xii). But Nozick is far more explicit than Pinker on the proto-political behavior of this magnificent faculty. Having subjugated other traits, Nozick writes, rationality "is proceeding now to remake the world to suit itself, altering not only its own environment but also that in which all other traits find themselves, extending the environment in which only it can fully flourish" (180).

This was too much for the equally distinguished philosopher Ian Hacking, who charged Nozick with describing a "biologically ordained mastery of the universe and its denizens" by 
Western rationalists (Hacking 1994a, 17; see also Janicaud 1994). To which Nozick immediately replied, condemning Nazism and racism in no uncertain terms, and denouncing Hacking's letter as "bizarre," "irresponsible," "slanderous," and "loathsome" (Nozick 1994). Neither this reply nor Hacking's bland and exhausted reply to Nozick either clarified the issue or, for that matter, exemplified rationality (Hacking 1994b).

But an important point was raised in the focus on the phrase "extends its sway," which struck Hacking as profoundly offensive and dangerous because evocative of political-military regimes with the same tendency. The question is whether Pinker's sway-extending triumvirate of reason, science, and humanism might be open to the same charge. If we believe that "biologically ordained mechanisms" are constantly extending their sway within us, helping us to make our world beautiful, then might we not also believe that we have a species-imperative to extend our sway-our values and practices-over other societies less in tune with their humanity? And if so, are we not painfully exposed to the charge that in seeing the entire world through the filter of "enlightenment" we are just providing a fancy justification for the domination of the West? One would like to hear Pinker on this question.

One would also like to hear Pinker tell us why science should be trusted when it consistently generates new truths, whether through new experimental results, new procedures, new technologies, or breakthrough theoretical advances. Why should we trust the "scientific method" when, according to Pinker, there is no such thing, and scientists "use whichever methods help them understand the world: drudgelike tabulation of data, experimental derring-do, flights of theoretical fancy, elegant mathematical modeling, kludgy computer simulation, sweeping verbal narrative" (392)? The only constants in science, according to Pinker, are a commitment to intelligibility and empiricism-admirable commitments, but the same ones that gave us the results we are now disconfirming. What, in the end, is the difference between science and its evil twin pseudo-science or its degenerate cousin bad science, when science is always rejecting its own previous results or conclusions?

And, finally, one would like to have Pinker respond to the point that all the problems now being so efficiently solved by enlightenment were caused by us in the first place. Does our evolved brain contain, in addition to a self-correcting mechanism, a self-sabotaging or self-interfering mechanism? And can we count on triumphing over entropy every time, when world-destroying capacities are within our reach, and a lost battle might end the war? And might not a state if not of fatalism at least of grave alarm be more appropriate to some challenges?

In short, one would like to hear more from Pinker, and if history is any guide, we surely will. Enlightenment Now is a magnificently bold and provocative book. It's a great read, endlessly stimulating, a model of reasoned and fact-based argumentation, and heartening not least in its invitation to debate. John Gray calls it a "rationalist sermon delivered to a congregation of wavering souls" with the implication that that's a paltry and meretricious thing. But many people whose efforts are now needed are in fact wavering, and wavering will not save us.

\section{WORKS CITED}

Bell, David A. 2018. "The PowerPoint Philosophe." The Nation 7 March: https://www.thenation.com/article/waiting-for-steven-pinkers-enlightenment/.

Benjamin, Walter. 1969. “Theses on the Philosophy of History." In Hannah Arendt, ed., Illuminations, 253-64. New York: Shocken Books. 
Carey, M., Jackson, M., Antonello, A., \& Rushing, J. 2016. "Glaciers, Gender, and Science." Progress in Human Geography 40.6, 770-93.

Chomsky, Noam. 1977. Language and Responsibility. Based on conversations with Mitsou Ronat; trans. John Viertel. New York: Pantheon Books, 1977.

Gates, Bill. 2018. "My New Favorite Book of all Time." Gatesnotes 26 January: https://www.gatesnotes.com/Books/ Enlightenment-Now.

Gray, John. 2018. "Unenlightened Thinking: Steven Pinker's Embarrassing New Book is a Feeble Sermon for Rattled Liberals." The New Statesman 22 February: https://www.newstatesman.com/culture/books/2018/02/unenlightened-thinking-steven-pinker-s-embarrassing-new-book-feeble-sermon.

Hacking, lan. 1994a. "What's Best." London Review of Books 27 January: 17-18. . 1994b. Reply to Robert Nozick. London Review of Books 24 March: 4.

Hume, David. 2007. A Treatise on Human Nature: A Critical Edition. Ed. David Fate Norton and Mary J. Norton. Oxford UK: Clarendon Press.

Janicaud, Dominique. 1994. Powers of the Rational: Science, Technology, and the Future of Thought. Bloomington: Indiana University Press.

Nietzsche, Friedrich. 1954. "On Truth and Lies in an Extra-Moral Sense." In Walter Kaufmann, ed., The Portable Nietzsche, 42-46. New York: Viking Press.

Nozick, Robert. 1993. The Nature of Rationality. Princeton: Princeton University Press. 1994. Reply to lan Hacking. London Review of Books, 10 March: 4-5.

Pinker, Steven. 1994. The Language Instinct: How the Mind Creates Language. New York: William Morrow \& Company.

-_- 2011. The Better Angels of Our Nature: Why Violence Has Declined. New York: Viking.

Pinker, Steven, and P. Bloom, P. 1990. "Natural Language and Natural Selection." Behavioral and Brain Sciences 13.4: 707-784.

Semley, John. 2018. "Review: In Enlightenment Now, Steven Pinker Would Like you to Know that Everything-Everything-is Okay." The Globe and Mail, 28 February: https://www.theglobeandmail.com/arts/books-andmedia/book-reviews/review-in-enlightenment-now-steven-pinker-would-like-you-to-know-that-everything-everything-is-okay/article38143784/.

Sontag, Susan. 1969. "Some Thoughts on the Right Way (for us) to Love the Cuban Revolution." Ramparts April: 16-19. Spencer, Nick. 2018. "Enlightenment and Progress, or Why Steven Pinker is Wrong." At: https://www.theosthinktank. co.uk/comment/2018/02/20/enlightenment-and-progress-or-why-steven-pinker-is-wrong.

Szalai, Jennifer. 2018. "Steven Pinker Wants You to Know Humanity is Doing Fine. Just Don't Ask about Individual Humans." New York Times, 28 February; https://www.nytimes.com/2018/02/28/books/review-enlightenment-now-steven-pinker.html.

Trump, Donald J. 2016. Acceptance speech at Republican National Convention ("I alone can fix it"): http://abcnews. go.com/Politics/full-text-donald-trumps-2016-republican-national-convention/story?id=40786529. 